medRxiv preprint doi: https://doi.org/10.1101/2020.06.02.20120477; this version posted June 4, 2020. The copyright holder for this preprint (which was not certified by peer review) is the author/funder, who has granted medRxiv a license to display the preprint in perpetuity. All rights reserved. No reuse allowed without permission.

\title{
Detection of asymptomatic SARS-CoV-2 exposed individuals by a sensitive S-based ELISA.
}

Ebba Rosendal ${ }^{1,3 *}$, Julia Wigren Byström ${ }^{1 *}$, Remigius Gröning ${ }^{1}$, Yong-Dae Gwon ${ }^{1}$, Emma Nilsson ${ }^{1,3}$, Atin Sharma ${ }^{2,3}$, Akbar Espaillat ${ }^{2,3}$, Leo Hanke ${ }^{4}$, Therese Thunberg ${ }^{1}$, Gerald McInerney $^{4}$, Andrea Puhar ${ }^{2,3}$, Felipe Cava ${ }^{2,3}$, Gunilla B Karlsson Hedestam ${ }^{4}$, Tor Monsen ${ }^{1}$, Fredrik Elgh ${ }^{1}$, Bert Blomkvist ${ }^{1}$, Ingrid Marklund ${ }^{1}$, Clas Ahlm ${ }^{1}$, Magnus Evander ${ }^{1}$, Johan Normark $^{1}$, Anders Johansson ${ }^{1}$, Anna K Överby ${ }^{1,3 \#}$, Mattias NE Forsell ${ }^{1 \#}$

Departments of ${ }^{1}$ Clinical Microbiology, ${ }^{2}$ Molecular Biology or ${ }^{3}$ Laboratory for Molecular Infection Medicine Sweden, Umeå University, Sweden and ${ }^{4}$ Department of Microbiology, Tumor and Cell Biology, Karolinska Institutet, Sweden

${ }^{*}$, Equal contribution

Correspondence: anna.overby@umu.se,mattias.forsell@umu.se

\begin{abstract}
To assess the current coronavirus pandemic, there is a pressing need to determine the exposure and seroconversion to SARS-CoV-2 on a local and global level. Here, we demonstrate a sensitive and specific S-protein based assay that is well suited for detection of weak SARS$\mathrm{CoV}$-2-directed IgG responses, and that could identify exposed individuals with asymptomatic infection without the requirement of PCR diagnostics. Our results raise the possibility that ongoing population-based studies using less sensitive state-of-the-art serological assays may significantly underestimate the frequency of exposure and seroconversion to SARS-CoV- 2 .
\end{abstract}

\section{Main text}

During the current COVID-19 pandemic there is an urgent need to accurately assess seroconversion to SARS-CoV-2 on an individual and population basis ${ }^{1-3}$. On the individual level, seroconversion and development of isotype-switched antibodies, particularly IgG, likely reflects the development of $\mathrm{B}$ and $\mathrm{T}$ cell memory. Based on knowledge from other coronavirus infections, this is assumed to confer protection also against re-infection ${ }^{4}$. Accordingly, information about the proportion of individuals who have seroconverted is critical to predict the likelihood of reaching herd immunity, as well as to devise and monitor strategies to reduce further cases of COVID-19. It is widely accepted that patients with clinical COVID-19 develop robust isotype-switched antibody-responses to SARS-CoV-2 within 15-20 days of disease onset $^{5,6}$, and these are readily detected by many currently available serological assays. However, a large majority of all SARS-CoV-2 infections are asymptomatic or manifest with mild disease ${ }^{7,8}$. Based on that mild or absent disease symptoms likely result in a relatively weak adaptive immune responses to SARS-CoV-2, these individuals may produce low level of IgG to the virus ${ }^{9}$. Without sensitive methodology, these may not be detected in current serological studies, and result in an underestimation of the frequency of exposure to SARS-CoV- $2^{10}$.

To meet the needs of the Clinical Microbiology laboratory at Umeå University Hospital, Sweden, we were tasked to developed an in-house ELISA with increased sensitivity

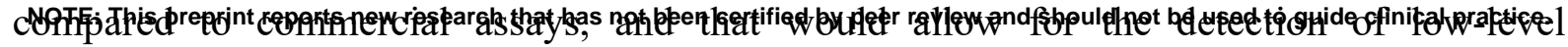


medRxiv preprint doi: https://doi.org/10.1101/2020.06.02.20120477; this version posted June 4, 2020. The copyright holder for this preprint (which was not certified by peer review) is the author/funder, who has granted medRxiv a license to display the preprint in perpetuity. All rights reserved. No reuse allowed without permission.

seroconversion to the SARS CoV-2 Spike (S) glycoprotein in asymptomatic individuals or those with mild COVID-19. While correlates of protection against SARS-CoV-2 infection remain to be determined, it is clear that neutralizing antibodies bind to the spike protein of SARS-CoV-2 that facilitates attachment and entry into target cells ${ }^{11,12}$. Accordingly, we produced recombinant trimeric S proteins from the SARS-CoV-2 isolate Wuhan $\mathrm{Wu}^{13}$ and used these as antigen for an ELISA. The assay was initially set up with small modifications to what was recently described ${ }^{13}$. After confirmation that detection of S-directed IgG was concentration-dependent in the horse radish peroxidase (HRP)-based S ELISA (Figure 1A), we evaluated it for detection of anti-SARS-CoV-2 S protein-directed IgG in a single dilutionpoint format. For this purpose, we used samples from a panel of PCR-confirmed COVID-19 cases and 127 pre-COVID-19 control samples (Supplemental table 1). As expected, the detection of anti-S IgG increased with time with strong S-binding in all samples 15 days or more from COVID-19 disease onset (Figure 1B). The mean OD of controls in this assay was 0.17 and standard deviation was $+/-0.062$. We could also determine that the strength of detected S-binding in the HRP S ELISA correlated well with in vitro neutralization of SARS-CoV-2 infection of VeroE6 cells in two different formats; immunofluorescence and plaque reduction, respectively (Figure 1C, Supplemental figures 1A-E). No significant cross neutralization of SARS-CoV-2 was noted for in serum from individuals infected with other human coronaviruses (Supplemental figure 1F). To optimize the ELISA assay further, we made minor alterations to the set-up, including change from HRP- to an alkaline phosphatase- (AP) conjugated secondary antibody and standardization of temperature and time for the enzymatic reaction. For validation, we expanded our control panel with and additional 17 samples from individuals with active (IgM+) RSV or EBV (Supplemental table 1), as we had observed a tendency that similar control samples had slightly higher background in the original control set. The average OD of the 144 control samples used to validate the AP S ELISA was 0.06 in this setting and the standard deviation $+/-0.12$. In this study, we set the threshold for a "anti-S IgG positive sample" to $\mathrm{OD}>0.7$, which corresponds to the mean +5.8 standard deviations of control samples. The detection rate of confirmed COVID-19 samples was 1/5, 9/12 or 13/13 of COVID-19 samples from days 1-5, 6-14 and over 14, respectively (Figure 1D). This accounted for $77 \%$ of all COVID-19 samples, irrespective of day of sampling. In comparison, the HRP S ELISA, by similar calculation of cut-off (average +5.8 Standard deviations) accounted for $67 \%$ of COVID19 samples. Similar to the HRP S ELISA, we found a correlation between the strength of signal in the AP S ELISA and neutralization (Figure 1E). The increased sensitivity of the AP S ELISA was mainly due to strong detection of samples with "mid range" S-reactivity the HRP based assay (Figure 1F). This suggested that the AP S ELISA was more suitable for detection of weak anti-S responses during early SARS-CoV-2 infection than the HRP S ELISA.

Before implementation of the in house AP S ELSA in clinical work, we proceeded to cross-validate it with two commercially available assays with good sensitivity and specificity; one that measured IgG to the nucleocapsid (N) protein (Abbott Architect 1 SARS$\mathrm{CoV}-2 \mathrm{IgG})^{14}$ and one that measured IgG to the $\mathrm{S} 1$ and $\mathrm{S} 2$ domains of the $\mathrm{S}$ protein from SARSCoV-2 (LIAISON ${ }^{\circledR}$ SARS-CoV-2 S1/S2 IgG) ${ }^{15}$. For this purpose, we used a reduced panel with 23 PCR+ COVID-19 samples and 30 control samples (Figure 2A-C). This comparison revealed that our AP S ELISA could detect S-directed IgG in 63\% samples from day 1-14 COVID-19, whereas the N-based ELISA detected $44 \%$ and the S1/S2 38\%. As expected, the difference between the assays was reduced when samples from COVID-19 patients at later time-points, with our AP S-ELISA detecting all samples and the two commercial assays only missing one each. As a final test of sensitivity between the assays, we utilized a set of 145 blinded samples from a Swedish care home for elderly with confirmed COVID-19 cases. These samples were taken as part of a successful effort to contain the COVID-19 outbreak. With the AP S-ELISA, 
medRxiv preprint doi: https://doi.org/10.1101/2020.06.02.20120477; this version posted June 4, 2020. The copyright holder for this preprint

(which was not certified by peer review) is the author/funder, who has granted medRxiv a license to display the preprint in perpetuity. All rights reserved. No reuse allowed without permission.

we could detect $17 / 145(11.7 \%)$ individuals with reactivity to the S-protein, whereas the Nbased method detected $10(6.8 \%)$ and the S1/S2-based method defined 12 serum samples as positive (Figure 2D). However, three of the samples that were positive in the S1/S2-based method were negative by both the AP S-ELISA and the N-based method, this suggested that they were false positives and the detection rate was estimated to $9 / 145(6.2 \%)$. The 7 unique samples detected in the AP ELISA included 3 individuals with mild symptoms and 4 that were asymptomatic (Supplemental table 2). Overall, significantly more individuals that had scored positive than negative in the AP S ELISA had reported symptoms of fever, cough, muscle ache and loss of taste, whereas a large number of other symptoms did not differ (Supplemental table 2). Since binding to $S$ in the ELISA was abrogated by pre-incubation with an excess of soluble $\mathrm{S}$, we could verify that these were specific for the S protein of SARS-CoV-2 and therefore true positives (Figure 2E). We also managed to secure follow up samples of 6 of the unique individuals 9-22 days after the initial bleed. Of these, 5 serum samples had similar or slightly increased IgG levels at respective follow up time-point, whereas 1 serum sample dropped below detection level (Figure 2F). These data indicated a variable longitudinal development of humoral immune responses in asymptomatic or mild COVID-19, in contrast to the development of strong anti-S IgG over time during clinical COIVD-195.

In summary, we demonstrate the set-up and validation of highly sensitive method for detection of IgG seroconversion to the S protein of SARS-CoV-2. Our data suggest that it is possible to identify asymptomatic individuals via the detection of such low anti-S IgG responses. This may prove to be an advantage over current PCR-based methodology that relies on detection of SARS-CoV-2 viral RNA, as IgG is relatively stable in circulation over time. Thus, the AP S ELISA presented here may therefore be suitable to more easily identify and study protective correlates in individuals that have been mildly affected or unaffected by exposure to SARS-CoV-2.

Finally, we could show that the exposure and seroconversion among staff and tenants at care home for elderly in Sweden was calculated to be almost twice than estimated by two state-of-the-art commercial assays. This highlights that assays optimized for detection of SARS-CoV-2-specific antibody responses during the third week of clinically relevant COVID19 may radically underestimate both exposure and seroconversion if used for large scale studies. Hence, we propose that future serological studies should use assays that are optimized for detection of low-level responses. Our data also suggests that the AP S ELISA demonstrated here, in combination with a standard panel of immune serum or well-defined monoclonal antibodies, could be used as a benchmark against other assays currently in use. More sensitive assays, on a global scale, will provide more accurate data for prediction of SARS-CoV-2 spread and exposure and provide information for rational decisions in infectious disease control.

\section{Material and methods}

\section{Human samples}

All serum samples within this study were collected for clinical purposes within the realm of providing healthcare to patients in Region Västerbotten, Sweden and stored at the Department of Laboratory Medicine, Umeå University Hospital. In total, we investigated 30 samples from 25 hospitalized COVID-19 patients with moderate to severe disease and 144 samples from the clinical microbiology or immunology laboratory at Umeå University Hospital. In addition, 145 samples from staff and tenants at a care home for elderly sampled for the purpose of infection prevention and control were used in this study. Data on perceived symptoms collected by a questionnaire used in the clinical containment work were available for the whole cohort. The 
medRxiv preprint doi: https://doi.org/10.1101/2020.06.02.20120477; this version posted June 4, 2020. The copyright holder for this preprint (which was not certified by peer review) is the author/funder, who has granted medRxiv a license to display the preprint in perpetuity. All rights reserved. No reuse allowed without permission.

research was carried out according to The Code of Ethics of the World Medical Association (Declaration of Helsinki). Ethical permission was obtained from the Swedish Ethical review authority (No: 2020-01557).

\section{Protein production}

Plasmid encoding the 2019-nCoV S protein was kindly provided by Jason McLellan and the details of these constructs has been previously described ${ }^{16}$ Protein was produced using the $293 \mathrm{~F}$ system (Thermo Fisher Scientific). Briefly, plasmids encoding the 2019-nCoV S protein or the RBD of 2019-nCoV were transfected into the cells using Lipofectamine in a $1 \times 10^{6}$ cells $/ \mathrm{ml}$ culture and grown for 4-5 days in $8 \% \mathrm{CO}_{2}$ and 120rpm. The supernatant was then cleared of cells and debris by centrifugation and by passage through a $0.2 \mathrm{uM}$ filter. The supernatant was then flowed over column packed with His-pure Ni-NTA resin (Thermo Fisher Scientific) at a rate of approximately $0.5 \mathrm{ml} /$ minute. Subsequently the column was washed with 10 column volumes of $20 \mathrm{mM}$ Imidazole / PBS pH7.4 and then eluted with $250 \mathrm{mM}$ Imidazole / PBS pH 7.4. The resulting elute was concentrated and buffer exchanged to PBS pH7.4 by Amicon spin columns with a cut off $<100 \mathrm{kDa}$ (Sigma Aldrich). In an alternative set-up for purification of $\mathrm{S}$ protein for competition assays, the $\mathrm{S}$ protein was first captured via glycans in lentin-lectin cromatography (GE Healthcare), washed with PBS and then eluted with $0.5 \mathrm{M}$ Methyl- $\alpha-\mathrm{D}-$ mannopyranoside prior to loading of the elute on a Ni-NTA packed column. Protein purity was determined by SDS-page, native gel electrophoresis and concentration was determined by a BCA Protein Assay kit (Thermo Fisher Scientific).

\section{SARS-CoV-2 S ELISAs}

In this study, we used two SARS-CoV-2 Spike ELISA protocol: A highly sensitive AP S ELISA for clinical screening of seroconversion and a HRP S ELISA designed for research purposes. For both assays, we coated clear flat-bottom Immuno Maxisorp 96-well plates (Thermo Scientific) with $200 \mathrm{ng} /$ well of purified SARS-CoV-2 S protein and incubated the plates at $+4^{\circ} \mathrm{C}$ overnight. The following day the wells were washed once with PBS- $0.05 \%$ Tween (PBS-T) and incubated for $1 \mathrm{~h}$ at RT with blocking buffer (1\% non-fat dry-milk in PBS-T). In the AP S ELISA protocol, we added duplicates of heat-inactivated human serum samples that had been diluted 1/100 in blocking buffer. For each plate, control serum samples from a highly anti-S IgG positive individual, and blank wells with blocking buffer alone was also included. Susequently, we incubated the plates for $1 \mathrm{~h}$ at RT and then washed wells four times with PBS$\mathrm{T}$ and then added $100 \mu 1$ of goat-anti human IgG alkaline phosphate (AP)-conjugated antibody (\#A18814, Thermo Scientific) diluted 1/6000 in blocking buffer to each well and incubated for $1 \mathrm{~h}$ at $+37^{\circ} \mathrm{C}$. The wells were then washed four times with PBS-T, followed by addition of $100 \mu 1 /$ well of AP colourimetric substrate containing $1 \mathrm{mg} / \mathrm{ml}$ Phosphatase Substrate (\#S0942, Sigma-Aldrich) dissolved in diethanolamine buffer. We incubated the plate at $+37^{\circ} \mathrm{C}$ for 30 min, stopped the reaction with $50 \mu 13 \mathrm{M} \mathrm{NaOH}$ per well and the plate spectrophotometrically at $405 \mathrm{~nm}$ with Tecan Sunrise. The final OD calculated as $\mathrm{OD}_{405 \mathrm{~nm}}($ sample) - OD $405 \mathrm{~nm}$ (blank well.

We performed the HRP S ELISA protocol similarly, with following exceptions; The serum sample dilution was 1/50 in blocking buffer and as secondary we used a goat-anti human IgG horseradish peroxidase (HRP)-conjugated antibody (\#H10007, Thermo Scientific) diluted $1 / 5000$ in blocking buffer. The ELISA was developed with 1-Step Ultra TMB-ELISA (Thermo Scientific) and after incubation for 15 min we added $2 \mathrm{M}$ sulphuric acid as stop solution. The plate was read at $450 \mathrm{~nm}$ and all incubations was at RT.

\section{Spike competition assay}


medRxiv preprint doi: https://doi.org/10.1101/2020.06.02.20120477; this version posted June 4, 2020. The copyright holder for this preprint

(which was not certified by peer review) is the author/funder, who has granted medRxiv a license to display the preprint in perpetuity. All rights reserved. No reuse allowed without permission.

We performed a spike protein competition assay to verify inconsistent positive SARS-CoV-2 antibody results that differed between the S ELISA and the Architecht or Liaison instruments. Serum was diluted $1 / 10$ in PBS and purified S protein $(100 \mu \mathrm{g} / \mathrm{ml})$ or mock (PBS) was added and incubated for $1 \mathrm{~h}$ at RT. We diluted the serum/S protein mixture ten-fold with blocking buffer to obtain a final serum dilution of $1 / 100$ and added $100 \mu 1$ per well in duplicates to an $\mathrm{S}$ ELISA plate (200 ng S /well), which was previously blocked with blocking buffer. The HRP S ELISA was used for these purposes.

\section{Virus and plaque neutralization assay}

Vero E6 cells were cultured in Dulbecco's modified Eagle's medium (DMEM, D5648 Sigma) supplemented with $5 \%$ FBS (HyClone), 10 units $/ \mathrm{mL}$ penicillin and $10 \mu \mathrm{g} / \mathrm{ml}$ streptomycin (PeSt, HyClone). The patient isolate SARS-CoV-2/01/human/2020/SWE accession no/GeneBank no MT093571.1, was provided by the Public Health Agency of Sweden. The viral stock was grown in veroE6 cells for $48 \mathrm{~h}$ and titrated by plaque assay. Plaque assay: VeroE6 cells (4x105/well) were seeded in 12 well plates (VWR) $12-24 \mathrm{~h}$ prior to infection, and tenfold serial dilution of virus was added to the cells. We removed the virus inoculum after $1 \mathrm{~h}$ and added $2 \mathrm{ml}$ semisolid overlay containing DMEM $+2 \% \mathrm{FBS}+\mathrm{PeSt}+1.2 \%$ Avicel $\mathrm{RC} / \mathrm{CL}$ and cells were incubated at $37{ }^{\circ} \mathrm{C}$ in $5 \% \mathrm{CO}_{2}$. After $65 \mathrm{~h}$ the semisolid overlay was removed and cells were fixed with $4 \%$ formaldehyde for 30 min. Cells were washed with PBS and stained with $0.5 \%$ crystal violet in $20 \% \mathrm{MeOH}$ for 5 minutes. Plates were washed with water and the plaques counted. Plaque neutralization assay: Serum samples were heat inactivated at $56^{\circ} \mathrm{C}$ for 30 min prior to analysis. Ten-fold dilutions of sera were performed in virus stock (250 PFU/ml in DMEM + PeSt). The virus/sera mix was incubated at $37^{\circ} \mathrm{C}$ in $5 \%$ $\mathrm{CO}_{2}$ for $1 \mathrm{~h}$, then $400 \mu \mathrm{l}$ virus/sera inoculum was added to VeroE6 cells and plaque assay preformed as described above.

\section{Fluorescent inhibition assay}

Vero E6 cells (10\%/well) were seeded $12-24 \mathrm{~h}$ in 96 well plates (Greiner CELLSTAR ${ }^{\circledR}$ ) prior to infection. Heat inactivated serum samples were diluted $1: 10$ in virus solution $\left(10^{4} \mathrm{PFU} / \mathrm{ml}\right.$ in $\mathrm{DMEM}+\mathrm{PeSt}$ ) and then further five-fold serial diluted in same virus preparation. The virus/sera mix was incubated at $37^{\circ} \mathrm{C}$ in $5 \% \mathrm{CO}_{2}$ for $30 \mathrm{~min}$, then $50 \mu \mathrm{l}$ virus/sera inoculum was added to the cells and incubated for another $2 \mathrm{~h}$ at $37{ }^{\circ} \mathrm{C}$ in $5 \% \mathrm{CO}_{2}$. The inoculum was removed and $100 \mu 1$ media containing DMEM $+2 \%$ FBS + PeSt was added and the cells were incubated at $37^{\circ} \mathrm{C}$ in $5 \% \mathrm{CO}_{2} .8$ hours post infection the cells were prefixed by removing 50 $\mu \mathrm{l}$ of media and adding $50 \mu \mathrm{l}$ of $4 \%$ formaldehyde for $10 \mathrm{~min}$ at RT followed by fixation for 30 minutes in $4 \%$ formaldehyde. Plates were washed with PBS, permeabilized with $0.5 \%$ Triton $\mathrm{X}-100$ in PBS and $20 \mathrm{mM}$ glycine for $10 \mathrm{~min}$ at RT, followed by blocking with PBS containing $2 \%$ BSA for $30 \mathrm{~min}$ at RT. Virus infected cells was stained for $1 \mathrm{~h}$ with anti-SARS-CoV-2 N protein rabbit monoclonal antibody (Sino Biological 40143-R001) diluted 1:1000 in blocking buffer, followed by secondary donkey anti-rabbit $\operatorname{IgG}(\mathrm{H}+\mathrm{L})$ Alexa Fluor 488 antibody (Invitrogen) 1:1000 in blocking buffer for $30 \mathrm{~min}$ and DAPI staining $(0.1 \mathrm{ug} / \mathrm{mL}$ in PBS $)$ for 5 min. Number of infected cells were quantified using a TROPHOS Plate RUNNER HD ${ }^{\circledR}$ (TROPHOS SA, Marseille, France).

\section{Statistics}

Statistical analysis was performed by using Prism 8 (Graphpad software). Two-way ANOVA was used to determine the potential significance of detection of COVID-19 samples, as compared with controls. Correlative analysis was done by calculation of the Spearman $r$ correlation. One-way Fischer test and risk ratios were used to evaluate symptoms by SARSCoV-2 IgG assay result. 
medRxiv preprint doi: https://doi.org/10.1101/2020.06.02.20120477; this version posted June 4, 2020. The copyright holder for this preprint (which was not certified by peer review) is the author/funder, who has granted medRxiv a license to display the preprint in perpetuity. All rights reserved. No reuse allowed without permission.

\section{Acknowledgements}

We would like to acknowledge the Department of Clinical Microbiology, the Department of Infection Prevention and Control and the Department of Infectious Diseases, Region Västerbotten, Sweden and Umeå Center for Microbial Pathogenesis, and the Translational Research Center Umeå, Sweden for facilitating the research. We thank Pia Nilsson for managing contact tracing of the 145 persons at the care home and Peter Fjällström for statistical analyses of symptoms. The plasmid encoding the trimeric S protein used in this study was kindly provided by Dr Janson McLellan, University of Texas, TX, USA. Funding was through Intramural funds from the Medical Faculty, Umeå University AN2.2.1.2-76-14 to MF and in part by the National Institutes of health U19AI142777 to MNEF and CA, and The Swedish Science Council 2018-05851, 2017-02438, Kempestiftelserna SMK-1654 and JCK-1827 to AKÖ. Region Västerbotten and Umeå University to CA, Swedish Science Council and the Knut and Alice Wallenberg foundation to FC. AS is a postdoctoral fellow wihin the MIMS Excellence by Choice programme, under the patronage of Emmanuelle Charpentier SMK1532.2.

\section{Figure Legends}

\section{Figure 1. Validation and correlation between HRP and AP S ELISA and virus neutralization}

A. Titration of serum from qPCR confirmed Covid-19 positive individuals ( $\mathrm{N}=6$, blue) and control samples ( $\mathrm{N}=11$, black) in the HRP S ELISA. B. Single point validation of HRP S ELISA set up. Shown are qPCR confirmed Covid-19 1-5 days post disease onset $n=5,6-14$ days $n=12$ ,$>14$ days $n=13, h C o V n=18$, other viral infections $n=55$, rheumatoid arthralgia (RA) $n=9$ and healthy controls $n=43$. Dotted lines indicate threshold to define a positive sample $(O D=0.53)$ C. Correlation between HRP S ELISA and microneutralization at serum dilution 1/50. D. Validation of AP S ELISA. Dotted line indicate threshold to define a positive sample $(\mathrm{OD}=0.7)$ E. Correlation between AP S ELISA and microneutralization at serum dilution 1/50. F. Correlation between HRP and AP S ELISA. Colors represent COVID-19 samples from day 15 (grey), 6-14 (orange) and $>$ day 14 (red). ${ }^{*} \mathrm{p}<0.05 * * \mathrm{p}<0.01 * * * * \mathrm{p}<0.0001$

Figure 2. Increased detection of seroconversion among early COVID-19 patients and asymptomatic individuals by AP S ELISA

Side by side validation between (A) in-house AP S-ELISA, (B) Abbott Architect 1 SARS-CoV$2 \mathrm{~N} \mathrm{IgG}$ and (C) LIAISON ${ }^{\circledR}$ SARS-CoV-2 S1/S2 IgG methods. D. Seroconversion in a Swedish elderly home, as detected by the three methods compared in A-C. Positive samples $(\mathrm{OD}>0.7)$ in the S-ELISA is colored blue and discrepancies in detection levels are shown. Dotted lines indicate threshold: AP S ELISA OD 0.7, N index value 1.5 and S1/S2 $14 \mathrm{AU} / \mathrm{mL}$. E. Competitive binding to soluble $S$ protein of the 7 unique samples detected by the AP S ELISA (light blue circles) and the 3 additional samples detected in the S1/S2 assay (dark blue squares). F. anti-S IgG measured in serum samples in 6 of the low responders uniquely detected in the AP S ELISA. 
medRxiv preprint doi: https://doi.org/10.1101/2020.06.02.20120477; this version posted June 4, 2020. The copyright holder for this preprint (which was not certified by peer review) is the author/funder, who has granted medRxiv a license to display the preprint in perpetuity. All rights reserved. No reuse allowed without permission.

\section{Supplemental figure 1}

A. Representative images of inhibition of plaque formation after infection of VeroE6 cells by SARS-CoV-2 (isolate SARS-CoV-2/01/human/2020/SWE) at serial, dilutions 1/10, 1/100 and 1/1000. B. Viral growth of SARS-CoV-2 in VeroE6 cells 8, 16, $24 \mathrm{~h}$ post infection in 96 microtiter plate. Virus infection was visualized by immunofluorescence staining of the SARSCoV-2 N protein. C. Representative image of micro neutralization ( $8 \mathrm{~h}$ post infection) by Covid-19 positive serum, as detected by immunofluorescence. D. Comparison between the $50 \%$ neutralization capacity between plaque reduction neutralization and microneutralization of 5 positive Covid-19 sera with varying reactivity in the HRP S ELISA. E. Concentration of COVID-19 positive sera that neutralize $50 \%$ of SARS-CoV-2 compared to control grouped in 0-0.5 OD, 0.5-1 and $>1$ in HRP S ELISA. F. Infection rates compared to control of SARS-CoV2 incubated with sera from different $\mathrm{hCoV}$ at $1 / 50$ dilution.

\section{Supplemental table 1}

Inclusivity and exclusivity panel of 173 serum samples used for evaluation of the SARS-CoV2 IgG assay

\section{Supplemental table 2}

Symptoms by SARS-CoV-2 IgG assay result of 145 individuals sampled at a care home for elderly after containment of a COVID-19 outbreak.

\section{References}

1 Winter, A. K. \& Hegde, S. T. The important role of serology for COVID-19 control. Lancet Infect Dis, doi:10.1016/S1473-3099(20)30322-4 (2020).

2 Chan, J. F. et al. A familial cluster of pneumonia associated with the 2019 novel coronavirus indicating person-to-person transmission: a study of a family cluster. Lancet 395, 514-523, doi:10.1016/S0140-6736(20)30154-9 (2020).

3 Huang, C. et al. Clinical features of patients infected with 2019 novel coronavirus in Wuhan, China. Lancet 395, 497-506, doi:10.1016/S0140-6736(20)30183-5 (2020).

4 Huang, A. T. et al. A systematic review of antibody mediated immunity to coronaviruses: antibody kinetics, correlates of protection, and association of antibody responses with severity of disease. medRxiv, 2020.2004.2014.20065771, doi:10.1101/2020.04.14.20065771 (2020).

5 To, K. K. et al. Temporal profiles of viral load in posterior oropharyngeal saliva samples and serum antibody responses during infection by SARS-CoV-2: an observational cohort study. Lancet Infect Dis 20, 565-574, doi:10.1016/S1473-3099(20)30196-1 (2020).

6 Long, Q. X. et al. Antibody responses to SARS-CoV-2 in patients with COVID-19. Nat Med, doi:10.1038/s41591-020-0897-1 (2020).

7 Wang, Y., Wang, Y., Chen, Y. \& Qin, Q. Unique epidemiological and clinical features of the emerging 2019 novel coronavirus pneumonia (COVID-19) implicate special control measures. J Med Virol, doi:10.1002/jmv.25748 (2020).

8 Ing, A. J., Cocks, C. \& Green, J. P. COVID-19: in the footsteps of Ernest Shackleton. Thorax, thoraxjnl-2020-215091, doi:10.1136/thoraxjnl-2020-215091 (2020). 
medRxiv preprint doi: https://doi.org/10.1101/2020.06.02.20120477; this version posted June 4, 2020. The copyright holder for this preprint (which was not certified by peer review) is the author/funder, who has granted medRxiv a license to display the preprint in perpetuity. All rights reserved. No reuse allowed without permission.

9 Zhang, Z. et al. Early viral clearance and antibody kinetics of COVID-19 among asymptomatic carriers. medRxiv, 2020.2004.2028.20083139, doi:10.1101/2020.04.28.20083139 (2020).

10 Siracusano, G., Pastori, C. \& Lopalco, L. Humoral Immune Responses in COVID-19 Patients: A Window on the State of the Art. Frontiers in Immunology 11, doi:10.3389/fimmu.2020.01049 (2020).

11 Okba, N. M. A. et al. Severe Acute Respiratory Syndrome Coronavirus 2-Specific Antibody Responses in Coronavirus Disease 2019 Patients. Emerg Infect Dis 26, doi:10.3201/eid2607.200841 (2020).

12 Hoffmann, M. et al. SARS-CoV-2 Cell Entry Depends on ACE2 and TMPRSS2 and Is Blocked by a Clinically Proven Protease Inhibitor. Cell 181, 271-280 e278, doi:10.1016/j.cell.2020.02.052 (2020).

13 Amanat, F. et al. A serological assay to detect SARS-CoV-2 seroconversion in humans. Nat Med, doi:10.1038/s41591-020-0913-5 (2020).

14 Bryan, A. et al. Performance Characteristics of the Abbott Architect SARS-CoV-2 IgG Assay and Seroprevalence in Boise, Idaho. Journal of clinical microbiology, doi:10.1128/jcm.0094120 (2020).

15 GeurtsvanKessel, C. H. et al. Towards the next phase: evaluation of serological assays for diagnostics and exposure assessment. medRxiv, 2020.2004.2023.20077156, doi:10.1101/2020.04.23.20077156 (2020).

16 Wrapp, D. et al. Cryo-EM structure of the 2019-nCoV spike in the prefusion conformation. Science 367, 1260-1263, doi:10.1126/science.abb2507 (2020). 
medRxiv preprint doi: https://doi.org/10.1101/2020.06.02.20120477; this version posted June 4, 2020. The copyright holder for this preprint (which was not certified by peer review) is the author/funder, who has granted medRxiv a license to display the preprint in perpetuity.

Figure 1 All rights reserved. No reuse allowed without permission.

A

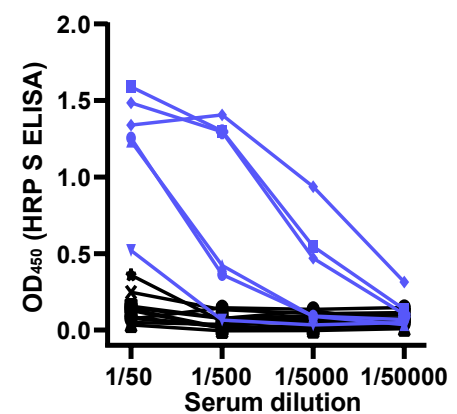

D

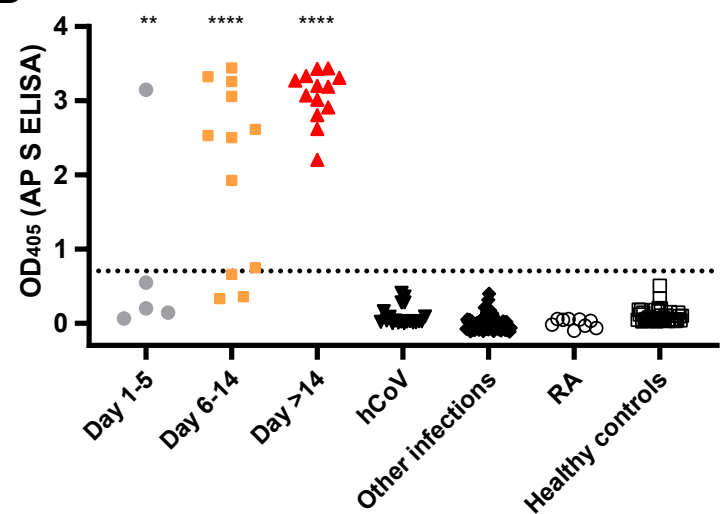

B

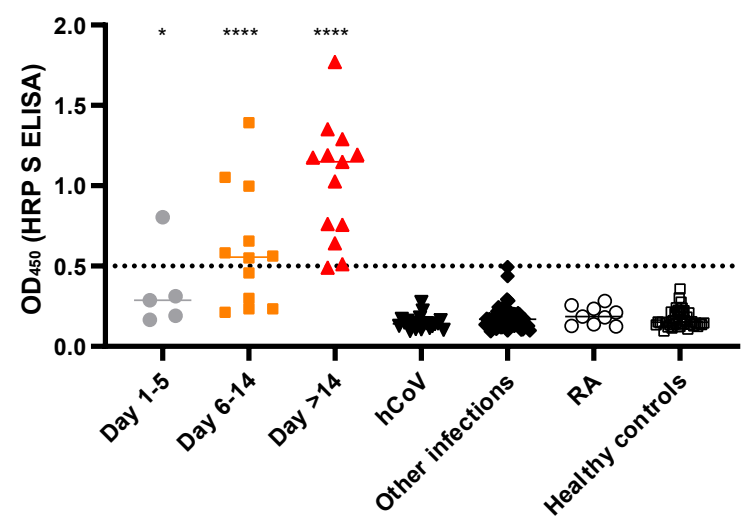

E

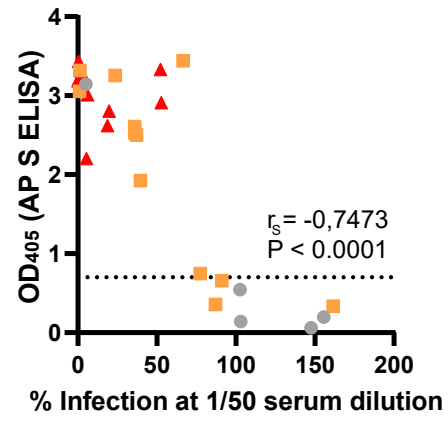

C

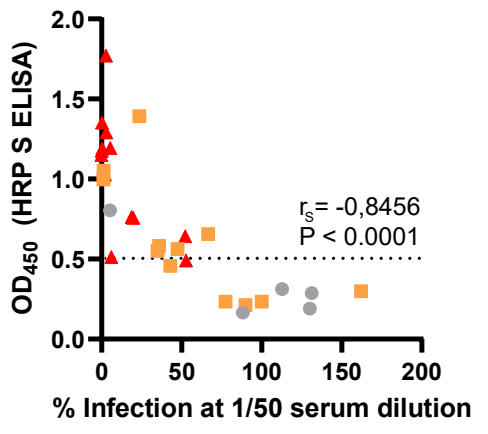

$\mathbf{F}$

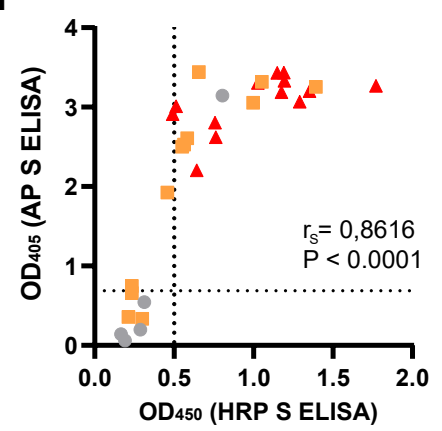


medRxiv preprint doi: https://doi.org/10.1101/2020.06.02.20120477; this version posted June 4, 2020. The copyright holder for this preprint (which was not certified by peer review) is the author/funder, who has granted medRxiv a license to display the preprint in perpetuity.

\section{Figure 2}

A

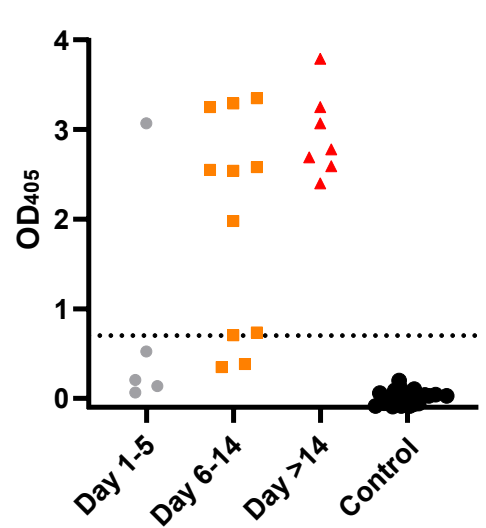

B

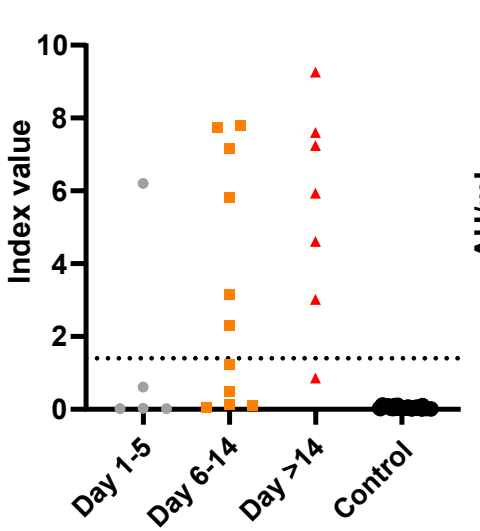

C

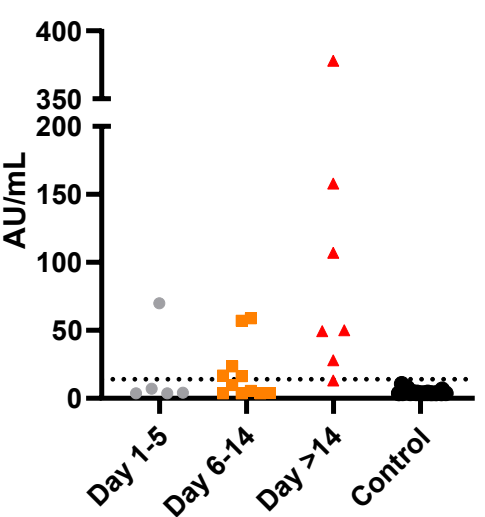

D AP S ELISA

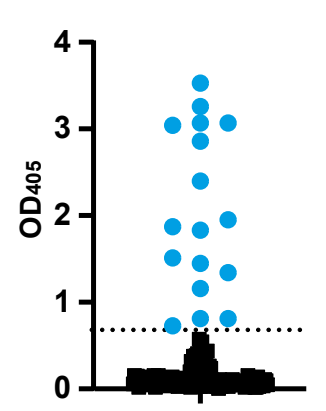

$\mathbf{N}$

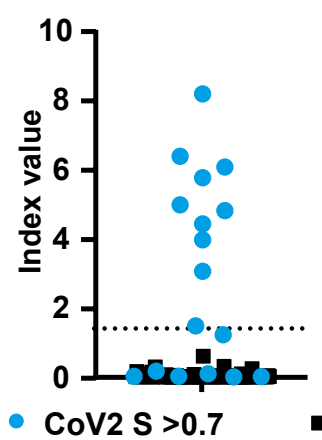

S1/S2

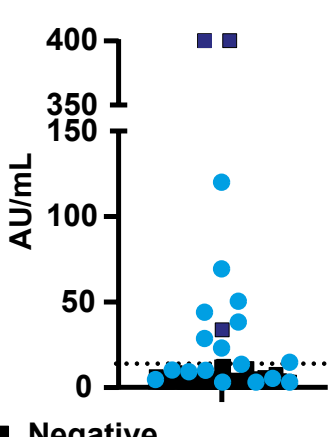

F

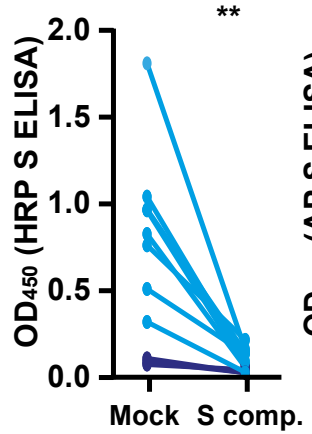

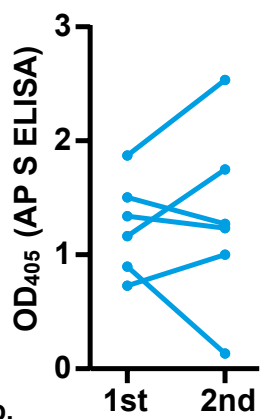


medRxiv preprint doi: https://doi.org/10.1101/2020.06.02.20120477; this version posted June 4, 2020. The copyright holder for this preprint (which was not certified by peer review) is the author/funder, who has granted medRxiv a license to display the preprint in perpetuity.

All rights reserved. No reuse allowed without permission.

Supplemental table 1: inclusivity and exclusivity panel of 173 serum samples used for evaluation of the SARS-CoV-2 IgG assay

\begin{tabular}{|c|c|c|c|}
\hline Sample & & No. & Comment \\
\hline $\begin{array}{l}\text { Inclusivity } \\
\text { sera }\end{array}$ & SARS-CoV-2 & 30 & PCR confirmed infections with COVID-19 \\
\hline \multirow[t]{13}{*}{$\begin{array}{l}\text { Exclusivity } \\
\text { sera }\end{array}$} & hCov & 9 & $\begin{array}{l}\text { Infections with beta coronavirus } \\
\text { OC43/HKU1 }\end{array}$ \\
\hline & hCov & 4 & $\begin{array}{l}\text { PCR confirmed infection with alpha } \\
\text { coronavirus NL63 }\end{array}$ \\
\hline & hCoV & 7 & $\begin{array}{l}\text { PCR confirmed infection with alpha } \\
\text { coronavirus } 229 \mathrm{E}\end{array}$ \\
\hline & $\begin{array}{l}\text { PCR or serology positive } \\
\text { samples for viral infections }\end{array}$ & 25 & $\begin{array}{l}\text { PCR workup of suspected viral infection had } \\
\text { been performed } 2017 \text {. Unknown etiology. }\end{array}$ \\
\hline & Influenza A & 5 & PCR confirmed infection with Influenza A \\
\hline & Influenza B & 5 & PCR confirmed infection with Influenza B \\
\hline & RSV & 13 & $\operatorname{lgM}+$ for RSV \\
\hline & EBV & 14 & IgM +for EBV \\
\hline & Parainfluenza & 5 & PCR confirmed infection with Parainfluenza \\
\hline & Metapneumovirus & 5 & $\begin{array}{l}\text { PCR confirmed infection with } \\
\text { Metapneumovirus }\end{array}$ \\
\hline & Rheumatoid factor antibody + & 8 & Known to frequently cross-react \\
\hline & Pregnant women & 20 & Known to frequently cross-react \\
\hline & Healthy control & 23 & - \\
\hline
\end{tabular}


medRxiv preprint doi: https://doi.org/10.1101/2020.06.02.20120477; this version posted June 4, 2020. The copyright holder for this preprint (which was not certified by peer review) is the author/funder, who has granted medRxiv a license to display the preprint in perpetuity. All rights reserved. No reuse allowed without permission.

Supplemental table 2: symptoms by SARS-CoV-2 IgG assay result of 145 individuals sampled at a care home for elderly after containment of a COVID-19 outbreak

\begin{tabular}{lllll} 
Symptom & $\begin{array}{l}\text { No. of individuals } \\
\text { positive for IgG } \\
\text { (\%) }\end{array}$ & $\begin{array}{l}\text { No. of individuals } \\
\text { negative for IgG } \\
\text { (\%) }\end{array}$ & Risk ratio & P value \\
\hline Headache & $5(29)$ & $40(31)$ & 0.94 & 0.75 \\
Stuffy nose & $3(18)$ & $30(23)$ & 0.75 & 0.85 \\
Pronounced tiredness & $5(29)$ & $17(13)$ & 2.21 & 0.11 \\
Joint pain & $3(18)$ & $11(9)$ & 2.05 & 0.26 \\
Sore throat & $3(18)$ & $23(18)$ & 0.98 & 0.69 \\
Diarrhea & $2(12)$ & $13(10)$ & 1.16 & 0.61 \\
Fever & $8(47)$ & $15(12)$ & 4.02 & $<0.01$ \\
Cough & $7(41)$ & $21(16)$ & 2.51 & $\mathbf{0 . 0 4}$ \\
Muscle ache & $6(36)$ & $12(9)$ & 3.76 & $\mathbf{0 . 0 2}$ \\
Abdominal pain & $0(0)$ & $13(10)$ & 0 & 1.0 \\
Loss of taste & $3(18)$ & $3(2)$ & 7.53 & $\mathbf{0 . 0 3}$ \\
Nausea & $1(6)$ & $13(10)$ & 0.58 & 0.87 \\
Loss of smell & $2(12)$ & $2(2)$ & 7.53 & 0.08 \\
Nose bleed & $1(6)$ & $4(3)$ & 1.88 & 0.57 \\
Chills or shivers & $3(18)$ & $6(5)$ & 3.76 & 0.12 \\
Shortness of breath & $2(12)$ & $6(5)$ & 2.51 & 0.17 \\
\hline No symtoms & $4(24)$ & $54(42)$ & 0.56 & 0.07 \\
\hline Number of individuals & 17 & 128 & & \\
\hline
\end{tabular}

${ }^{a}$ Hypotheses tested were antibody presence is associated with symptom and antibody absence is associated with no symptom. 